\title{
Comparative Integumentary Morphology in Four Species of Pipa (Anura: Pipidae) from Colombia
}

\author{
Sebastian Enrique Perez-Rojas ${ }^{1,2}$ \& Adriana Jerez ${ }^{1,3}$ \\ 1 Universidad Nacional de Colombia (UNAL), Facultad de Ciencias, Departamento de Biología, Laboratorio de Ecología Evolutiva. \\ Bogotá, D.C., Colombia. \\ 2 ORCID: https://orcid.org/0000-0001-7855-9101.E-mail: seperezr@unal.edu.co \\ ${ }^{3}$ ORCID: https://orcid.org/0000-0002-5995-5034. E-mail: arjerezm@unal.edu.co
}

\begin{abstract}
As most neotropical pipids, the four species of Pipa present in Colombia are poorly understood despite their particular biology. The tegument of these New-World pipids presents particular structures which variations have been hardly analyzed. Therefore, we aim to describe the morphological variations of the dermal flap, barbels, fingertips, and the lateral line pattern among these four species, focusing on changes during the ontogeny. The results of the study show that the dermal flap was exclusively found in P. pipa, while barbels are usually present in P. pipa but seldom in P. snethlageae. The lateral line pattern in the dorsum is shared by the four species, but $P$. pipa present more neuromast lines along the snout than $P$. snethlageae. These species were different from P. parva and $P$. myersi, which cannot be distinguished based on external morphology, as they were more similar in all lateral line elements and exhibited the same fingertip morphology. On the other hand, the fingertips of young individuals of $P$. pipa and $P$. snethlageae presented four simple distal lobes which bifurcate twice during the ontogeny, so that adults present sixteen lobes. The difference between species is observed in the fingertip morphology: $P$. pipa has all four lobes distally placed, but $P$. snethlageae has one pair more proximal. The tegument structures analyzed here have a taxonomic utility using external morphology for $P$. pipa and $P$. snethlageae, but for $P$. parva and $P$. myersi additional studies are necessary. For future research, evaluating the function and anatomy of these structures is important to the understanding these integumentary structures in Pipa.
\end{abstract}

Keywords. Dermal flap; Barbels; Fingertips; Lateral line; Ontogeny.

\section{INTRODUCTION}

Pipidae is a family of frogs highly specialized to an aquatic mode of life (Vitt \& Caldwell, 2014). Taking advantage of their exceptional fossil record (Bewick et al., 2012; Carvalho et al., 2019), keen interest in these particular frogs has arisen among scientists in different areas, from ontogeny to evolutionary studies (Cannatella \& Trueb, 1988; Cannatella \& Sá, 1993). This family occurs in the tropics, having a disjointed distribution. While Pipidae is more diverse in Africa, in the Americas the only genus present is Pipa with seven species found from Panamá to Brazil (Trueb \& Cannatella, 1986; Frost, 2020). As most anurans do, pipids show a wide complex of integumentary structures such as tubercles, keratinizations, barbels, and sensory organs like the lateral line system (LLS) (Duellman \& Trueb, 1994). Their tegument has been studied not only regarding the production of host-defense peptides and kynurenic acid known in a few species (Conlon \& Mechkarska, 2014; Mariano et al., 2015), but also about the LLS (Elepfandt \& Wiedemer, 1987; Shelton 1970; Quinzio \& Fabrezi, 2014).

The skin of Pipa has keratinized tubercles along all surfaces of the body and develops lobes at the distal end on the fingertips (Zippel, 2006). These lobes show different arrangements among species which are thought to work as tactile organs (Trueb \& Cannatella, 1986; Schütte \& Ehrl, 1987). Additionally, female Pipa are able to keep fertilized eggs in pits in the dorsal skin while they develop into free-feeding larvae or into fully metamorphosed frogs (Rabb \& Rabb, 1960; Trueb \& Cannatella, 1986; Greven \& Richter, 2009). These traits show the unique characterizing features and dynamism of the skin of this genus.

In Pipidae, morphological features such as the fingertip lobes, head shape, and the dermal flap have been traditionally used for taxonomic purposes. For example, Dunn (1948), Cochran \& Goin (1960) and Trueb \& Cannatella (1986) have used these traits to distinguish species in the genus Pipa. Previous remarks by Lynch \& Vargas-Ramírez 
(2000) and Acosta-Galvis et al. (2016) have documented that some integument features can vary in Colombian specimens of $P$. pipa and $P$. snethlageae. In fact, the morphology of the fingertips in P. pipa has shown some disparity in the number of lobes in earlier works of Filek (1967) and Ehrl et al. (1986). On the other hand, P. myersi and $P$. parva present distinctive arrangements and number of lobes as adults, while in post-metamorphic individuals the fingertips show a more similar morphology (Trueb, 1984). Both species occur at separate locations in northern South America, and osteological and morphological characteristics support their taxonomic status. Overall, discrepancy among diagnostic features cannot only cause inaccurate taxonomic determinations but also arise questions about what causes this ambiguity when considering the dynamism of the tegument in pipids.

A more thorough and precise characterization of and comparison among the four species of Pipa distributed in Colombia are required. In this study, we aim to review several integumentary characteristics such as tubercles, dermal flap, barbels, fingertip lobes, and LLS pattern to describe the variations within and among species, accompanied by their possible ontogenetic variations.

\section{MATERIAL AND METHODS}

\section{Specimens examined and sizes}

The specimens of Pipa pipa, P. snethlageae, P. myersi, $P$. parva were examined from the biological collections of these institutions: Instituto de Ciencias Naturales (Universidad Nacional de Colombia, ICN), Universidad de Los Andes (Andes-Am), Colección de Anfibios del Instituto de Investigación de Recursos Biológicos Alexander von Humboldt (IAvH-Am), Colección de anfibios del Museo de la Salle (Universidad de la Salle, MLS), Museo de Historia Natural "Lorenzo Uribe" (Universidad Javeriana, MUJ), and the Colección de anfibios del Instituto SINCHI (SINCHI). All individuals analyzed are listed in the Appendix 1. For the data collection, snoutvent length (SVL) were made with a digital caliper on preserved specimens and expressed in millimeters $(0.05 \mathrm{~mm} \pm$ ). The observations were made using a stereo-microscope Zeiss Stemi 2000. Pictures were taken with a Leica M 205 stereomicroscope with $\times 0.3$. The individuals were categorized as adult, juvenile or post-met-

Table 1. Sample size and ontogenetic categories for each species included in the study. In brackets the maximum value of SVL found on specimens. $N=$ number of specimens in collections. Age stages based on Müller (1914), Ruthven \& Gaige (1923), Trueb (1984), Trueb \& Cannatella (1986), Trueb et al. (2000).

\begin{tabular}{lcccc}
\hline & P. pipa & P. snethlageae & P. myersi & P. parva \\
\hline Adult size (mm SVL) & $105-171$ & $66-92(150.5)$ & $35.5-44(51.6)$ & $27-44(49.7)$ \\
& $\mathrm{N}=26$ & $\mathrm{~N}=14$ & $\mathrm{~N}=15$ & $\mathrm{~N}=12$ \\
Juvenile size (mm SVL) & $20-105$ & $66<$ & $35.5<$ & $27<$ \\
& $\mathrm{N}=38$ & $\mathrm{~N}=5$ & - & $\mathrm{N}=1$ \\
Post-Metamorphic size (mm SVL) & $20<$ & - & - & - \\
& $\mathrm{N}=19$ & - & - & - \\
\hline Total & $\mathbf{8 3}$ & $\mathbf{1 9}$ & $\mathbf{1 5}$ & $\mathbf{1 3}$ \\
\hline
\end{tabular}

amorphic based on SVL and the ranges in literature records or species descriptions (Table 1).

\section{Morphological characteristics}

The external morphological characteristics of the samples were considered for the analysis and review. The variation at the intra and interspecific level in this sampling of the Pipa distributed in Colombia were considered. These features included skin tubercles, dermal flap, barbels, fingertips lobes, and the integumentary sensory LLS. Specimens of different sizes were taken into account to characterize the variation related to developmental stages; however, it was only possible for P. pipa due to its representation in the collections.

Sex differences were not considered since precise sex determination has to be done by gonad examination. Disrupting the already scarce material in collections was not encouraged. Kretschmer \& Greven (2009) proposed that dorsal tubercles of $P$. parva are sexually dimorphic, but it is not clear how reliable this character is so far, and it is also known that the forearm diameter is sexually dimorphic in P. pipa (Zippel, 2006; Alves-Pinto et al., 2014), no other accurate approach to external dimorphic characteristics is known until now for all the four species.

The terminology for tegument characters follows Trueb \& Cannatella (1986) and Shelton (1970) for the lateral line nomenclature, allowing comparison among other species in the family in adult stages. However, when there was no apparent correspondence for the lines, the name was based on the topology of the lines in the body.

\section{RESULTS}

Integumentary structures such as the skin tubercles, the dermal flap, barbels, and the fingertip lobes are first described. Then, the lateral line pattern formed by neuromast stitches is presented and analyzed.

\section{Integumentary structures}

\section{Skin tubercles}

In P. pipa and P. snethlageae, the skin exhibited tubercles of three types (Fig. 1C). The first type is conical, spiny, and enlarged and visible without magnification. These tubercles are only present in the dorsal region closer to the neuromasts stitches. The second type is spiny, protuberant but also smaller and scattered around the previous type. The third type is the smallest, and it occurs on all surfaces of the body extending to the limbs and fingers, with the exception of the fingertips.

The smaller P. parva (Fig. 1A-B) and P. myersi (Fig. 1D) also exhibited three different types of tubercles. The first type is the largest with a smooth or spiny surface. These tubercles are conical plates rather widened at the base and located in the dorsum and ventral region. The 
second type is also conical and widened at the base but smaller. The third type of tubercles is spiny, tiny, and extended along all the surface of the body up to the limbs and fingers. In comparison with the larger species, tubercles are different in shape and texture but share the distribution along the body.

\section{Dermal flap}

This integumentary unpaired appendage is located at the ventral end of the upper lip and centered. This structure may extend slightly further from the snout (Fig. 2). The dermal flap was observed only in P. pipa specimens ( $N=83$, but five individuals lacked it completely. The most frequent morphology in adults was a long cylin- drical process with a rounded tip (Fig. 2A). This appendage exhibited different morphologies ranging among: (1) a distally wider and flattened end (Appendix 2), (2) a cylindric base with a bilobed or trilobed distal end (Fig. 2B), (3) a short cylindric process and a distally blunt end (Fig. 2C), (4) a small rounded structure (Fig. 2D) or (5) a flattened flap with an irregular end. By contrast, post-metamorphic and juvenile individuals ( $n=42 / 43$ ) exhibited a cylindrical dermal flap with the distal end wide and flattened or rounded (Fig. 2A).

In preserved specimens, the color of the dermal flap varied among white, cream, or brown. In most cases specimens, showed a dermal flap with smooth tegument, but a small number of adults presented a dermal flap with spiny tubercles (Appendix 2B).

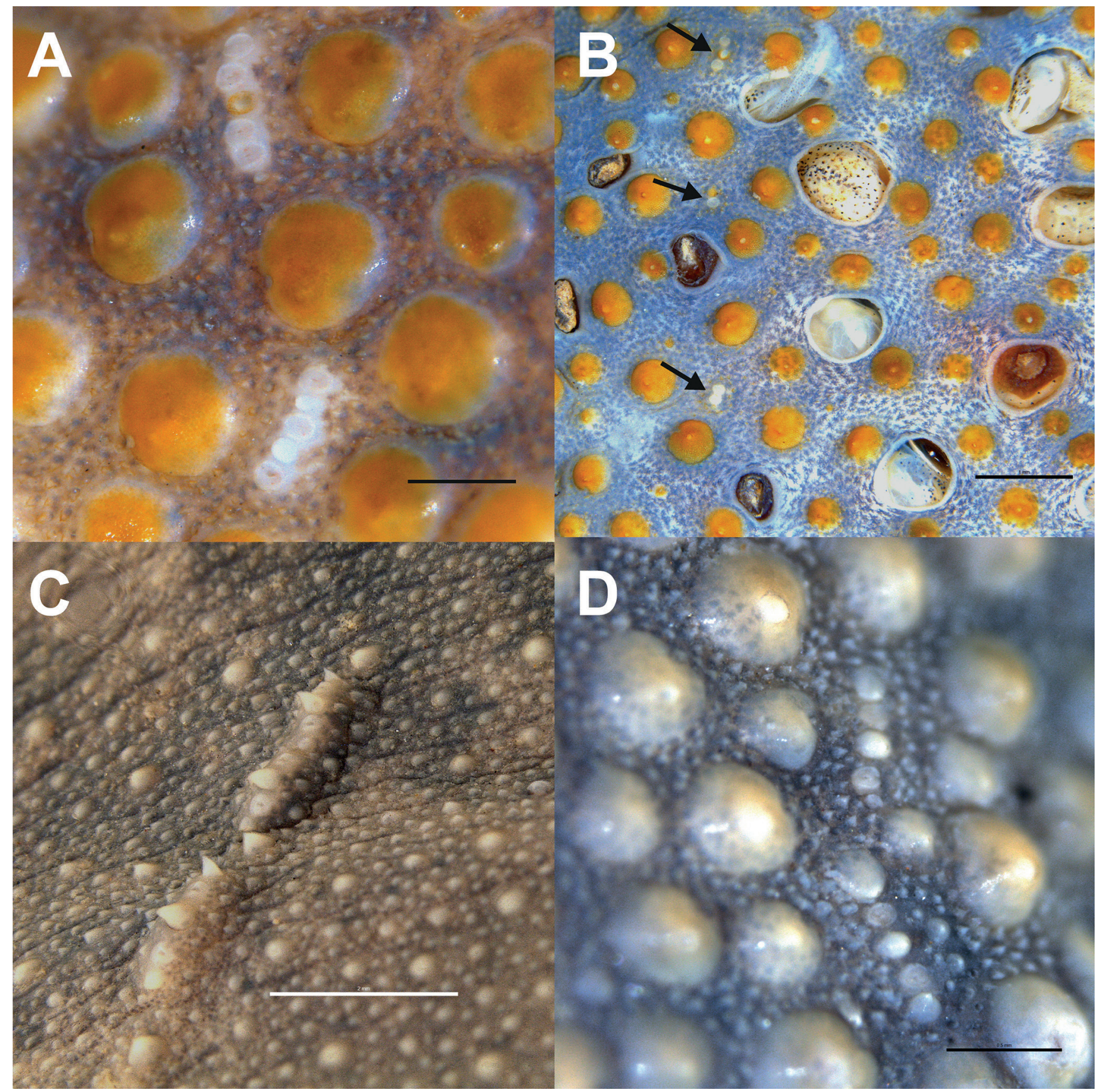

Figure 1. Neuromasts and tuberculation in the dorsal skin in Pipa, scale bar $=1 \mathrm{~mm}$. (A) Adult P.parva. (B) Adult female of P. parva with tadpoles within the dorsum, black arrows point to neuromasts. (C) Adult P. pipa and (D) Adult P. myersi. 


\section{Barbels}

Barbels are integumentary paired appendages located on the edge of the upper lip (Fig. 3). These structures were frequently found in $P$. pipa $(n=70 / 83)$, rarely in $P$. snethlageae $(n=3 / 19)$ and never observed in $P$. myersi ( $n=0 / 15)$ or in $P$. parva $(n=0 / 13)$. The barbels ranged from one up to four pairs, although just one specimen of $P$. pipa was observed with this last condition.

Barbels are cylindrical and thin processes found in the upper lip (Fig. 3), but some adult individuals presented flattened and wide barbels at the proximal portion $(n=4)$. Barbels exhibited variation in coloration in preserved specimens, from white to cream, or brown (like the dorsal skin). Specimens showed barbels with smooth skin or with tiny tubercles, like the tegument of the body (Fig. 3B).

\section{Fingertip lobes}

The lobes in the fingertips are present in all species analyzed, and each species has a particular morphology. Pipa pipa and $P$. snethlageae present four lobes which may present bifurcations (Figs. 4, 5). In the adults and juveniles of $P$. parva and $P$. myersi there are four simple lobes in the fingertips, two located distally and two more proximal (Fig. 6).

The lobes of $P$. pipa and $P$. snethlageae presented either four simple lobes, bifurcated lobes or tetrafurcated lobes at the tip. The lobes could also show different degrees of bifurcation among each finger; for example, one finger might have three bifurcated lobes and one simple lobe (Fig. 4B). As regards the position, in P. pipa all four lobes are located distally, while in $P$. snethlageae two lobes are usually placed at the distal tip and two placed slightly more proximal and lateral to the tip (Fig. 5). For both species there was a relationship between the number of bifurcations and the SVL, related to the ontogeny. As a result, it was observed that fingertips start with four simple lobes in post-metamorphic individuals and have bifurcated twice in the largest individuals (Fig. 7).

In $P$. pipa, simple non-bifurcate quadripartite fingertips (Fig. 4A) were present in post-metamorphic individuals ( $n=19 / 19)$, in some juvenile individuals $(n=14 / 24)$ as well as in a single adult specimen $(n=1 / 19)$. Bifurcated quadripartite fingertips (Fig. 4B) were present in a few juveniles $(n=10 / 24)$ around $82.2 \mathrm{~mm}( \pm 27.59 \mathrm{~mm} \mathrm{SVL}$, SD) and most adults $(n=11 / 19)$. Tetrafurcated fingertips were present in adults ( $\mathrm{n}=7 / 19)$, around $129.07 \mathrm{~mm}$ ( $\pm 55.68 \mathrm{~mm} \mathrm{SVL}, \mathrm{SD}$ ) (Fig. 4C), mostly the largest indi-

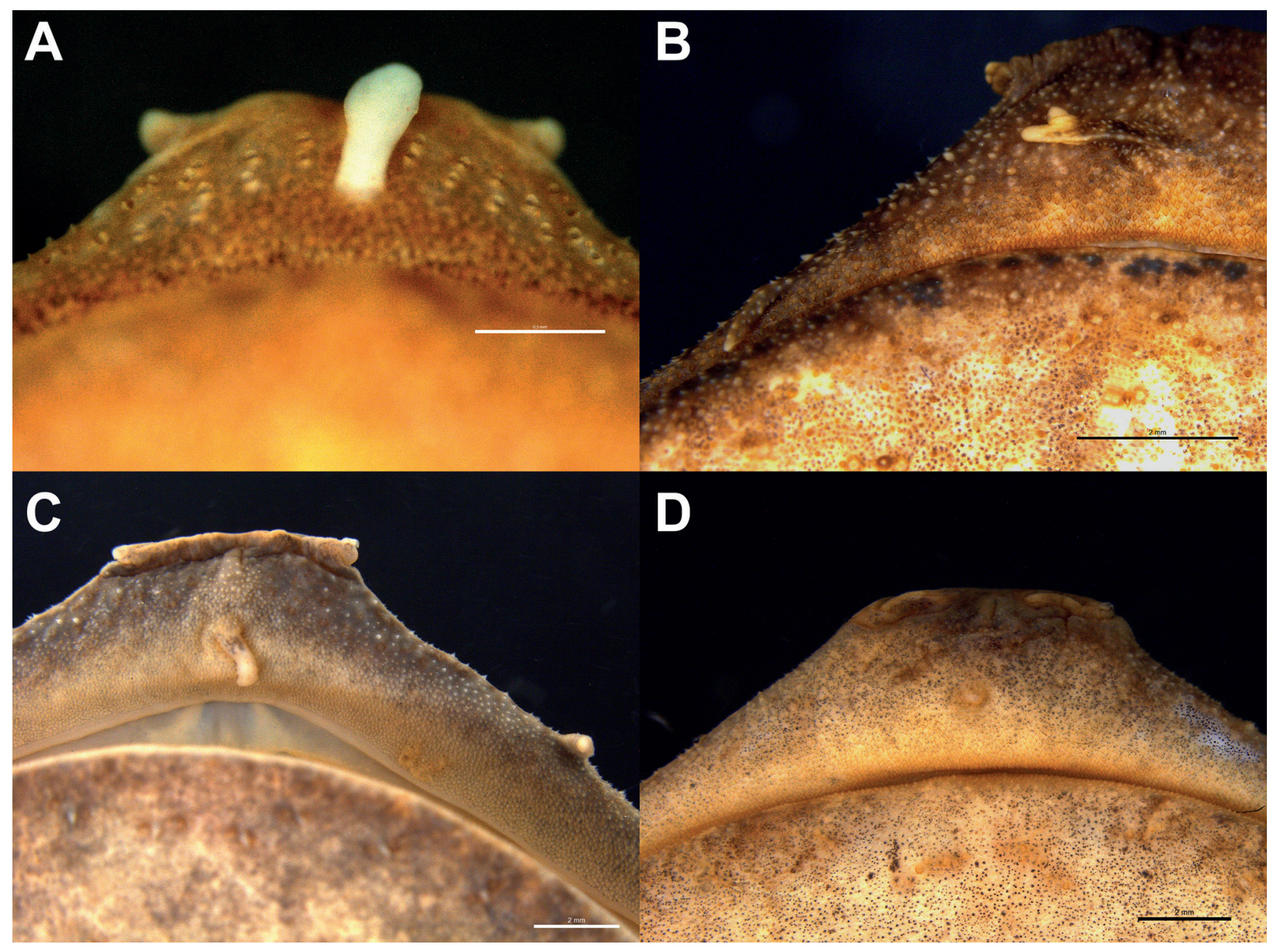

Figure 2. Variability on the morphology of the dermal flap in Pipa pipa (ventral view). (A) Post-metamorphic with wide-flattened flap, scale bar $=0.5 \mathrm{~mm}$. (B) Adult with bifid flap, scale bar $=2 \mathrm{~mm}$. (C) Adult with simple-cylindrical flap, scale bar $=2 \mathrm{~mm}$. (D) Adult with a reduced flap, scale bar $=2 \mathrm{~mm}$. 
viduals of our sample. The relationship between size and the number of bifurcations is summarized in Fig. 7. A rare condition was found in two specimens of P. pipa; one finger of the individual had a globular form at the tip, without any distinct lobes.

Pipa snethlageae exhibited a similar ontogenetic development as the one observed in P.pipa (Fig. 5), although the sample was smaller (Table 1). Simple quadripartite fingertips were present in juveniles $(n=3)$, the first bifur-

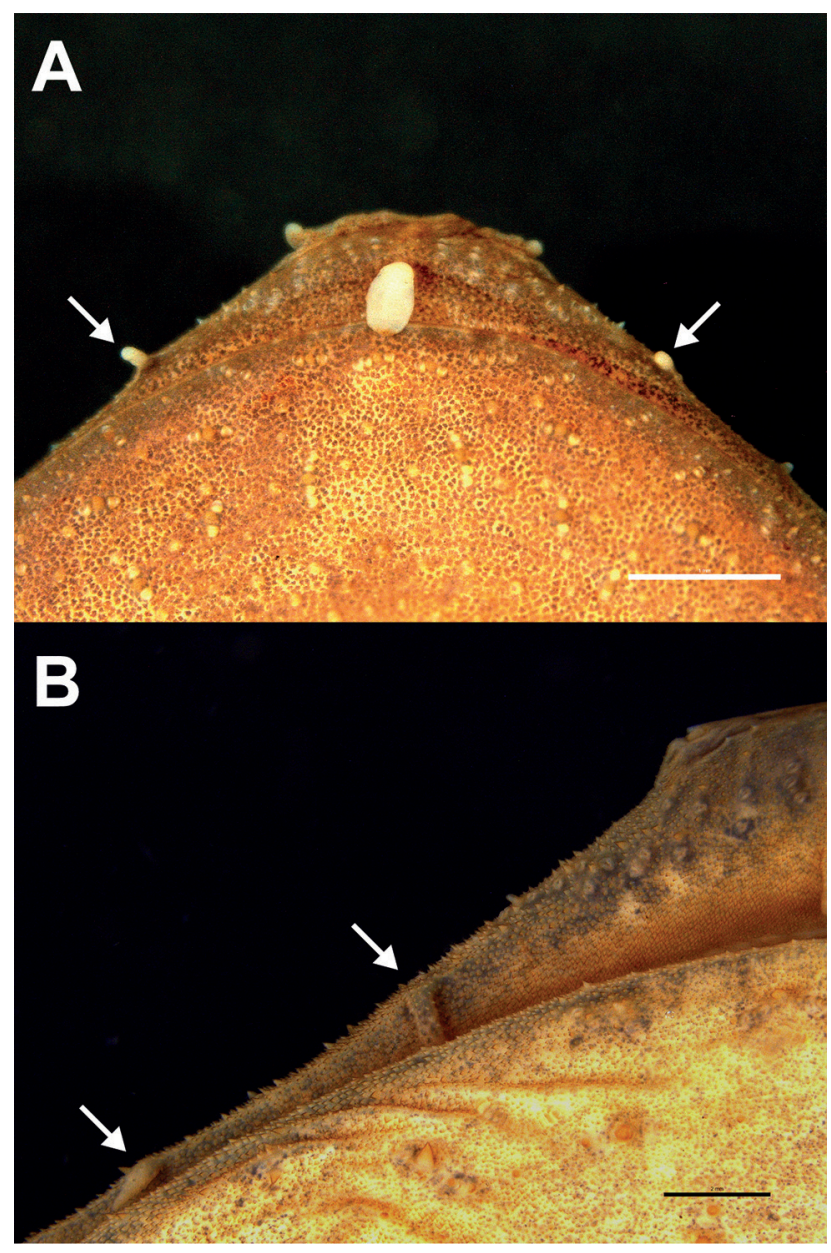

Figure 3. Barbels in Pipa pipa marked with an arrow (ventral view). (A) Postmetamorphic with one pair of barbels, scale bar $=0.5 \mathrm{~mm}$. (B) Adult with two pairs of barbels (one side of the head shown), scale bar $=2 \mathrm{~mm}$. cation was achieved in adults $(n=8 / 13)$ as the specimens reached around $87.52 \mathrm{~mm}( \pm 9.17 \mathrm{~mm}$ SVL, SD). Finally, tetrafurcated lobes (Fig. 5) were present in the largest specimens ( $n=5 / 13$ ) around 124.84 ( $\pm 27.13 \mathrm{~mm} \mathrm{SVL})$.
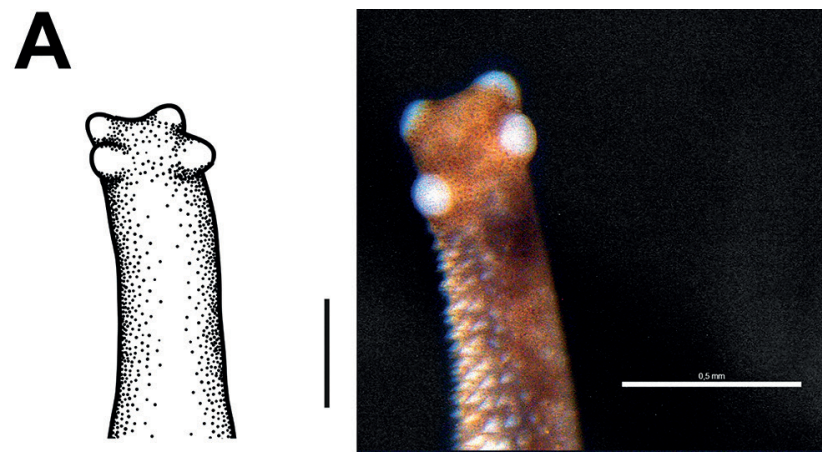

B
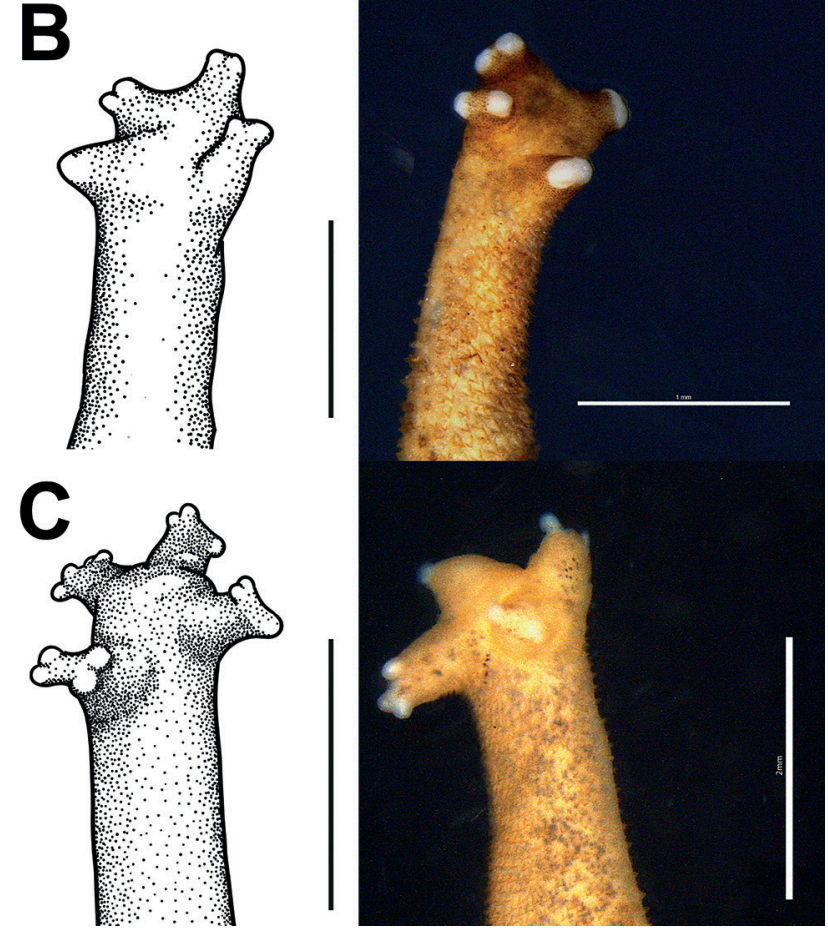

Figure 4. Fingertip morphology in P. pipa through ontogeny (Drawing data in parentheses). (A) Simple lobes in $24.10 \mathrm{~mm}$ SVL juvenile (16.70 mm SVL Post-metamorphic), scale bar $=0.5 \mathrm{~mm}$. (B) Bifurcated lobes in $84.71 \mathrm{SVL}$ juvenile (65.68 mm SVL juvenile), scale bar $=1 \mathrm{~mm}$. (C) Quadrifurcated lobes in $119.40 \mathrm{~mm}$ SVL adult (122.50 mm SVL adult), scale bar $=2 \mathrm{~mm}$.

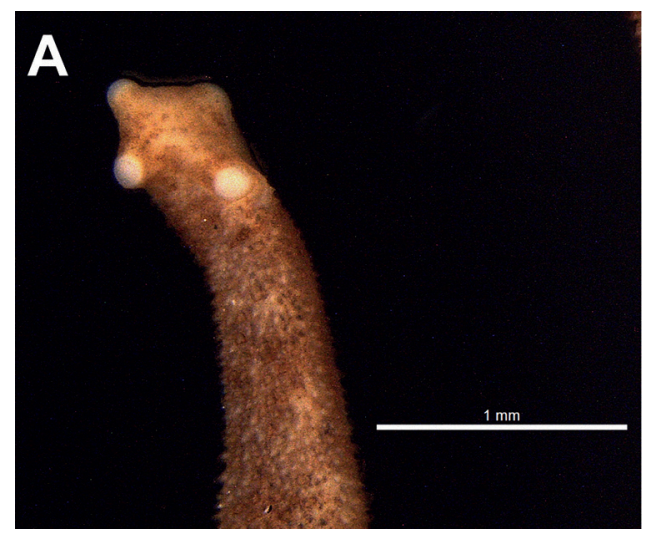

B

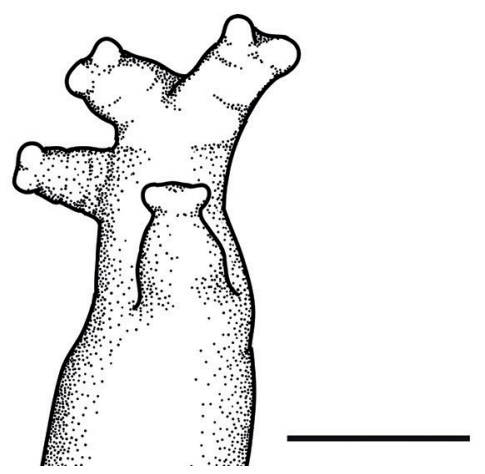

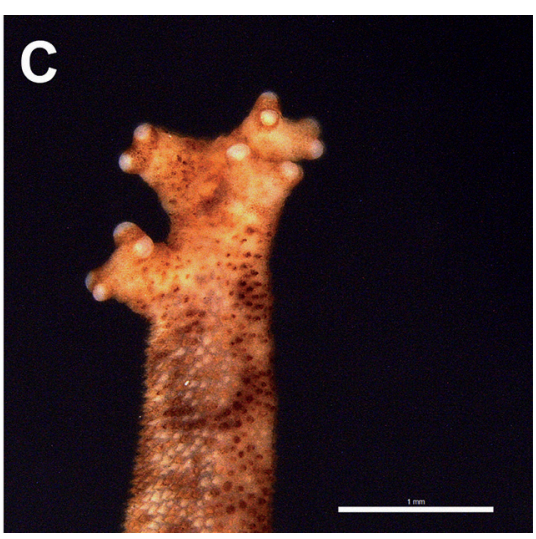

Figure 5. Fingertip morphology in P. snethlageae along ontogeny. (A) Simple lobes in $46.80 \mathrm{~mm}$ SVL juvenile, scale bar $=1 \mathrm{~mm}$. (B) Bifurcated lobes, adult $90.49 \mathrm{~mm}$ SVL, scale bar $=1 \mathrm{~mm}$. (C) Quadrifurcated lobes in $95 \mathrm{~mm}$ SVL adult, scale bar $=1 \mathrm{~mm}$. 
From our sample of P. parva, all individuals $(n=13)$ exhibited four small lobes (Fig. 6A). The fingertip presented two distal lobes and two more proximal lateral lobes. Similarly, in $P$. myersi $(\mathrm{n}=15)$ all adults exhibited the same morphology observed in P. parva (Fig. 6B), includ-
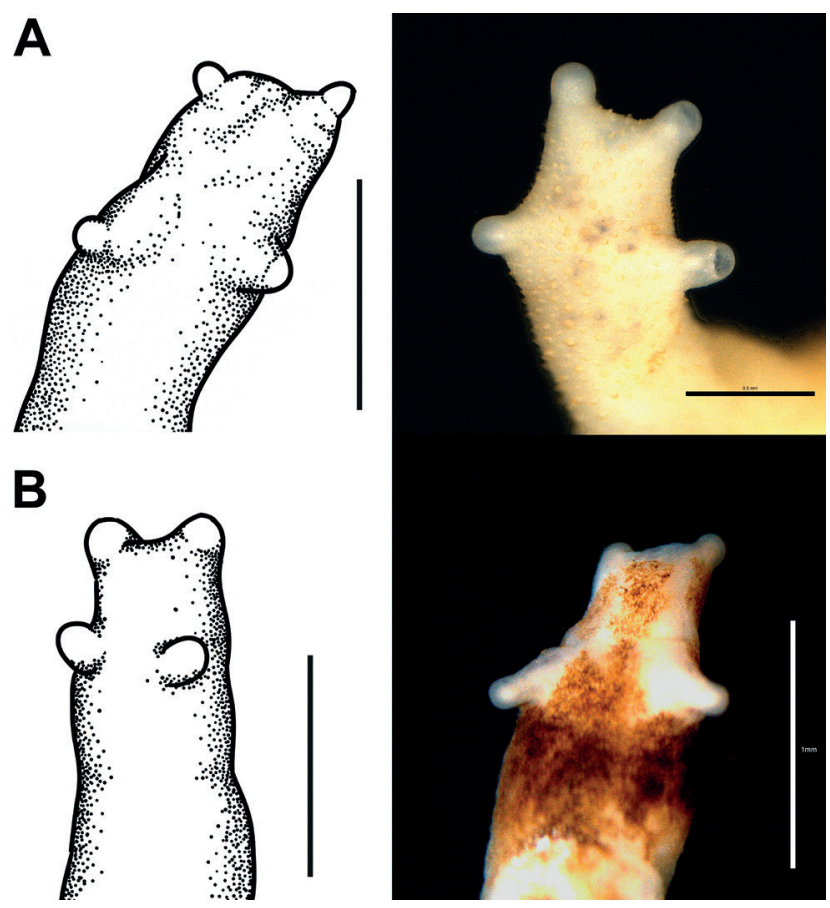

Figure 6. Fingertip morphology in the smaller species of Pipa (Drawing data in parentheses). (A) P. parva, $47 \mathrm{~mm} \mathrm{SVL}$ adult (43.11 mm SVL adult), scale bar $=1 \mathrm{~mm}$. (B) P. myersi, $37.96 \mathrm{~mm}$ SVL adult (51.65 mm SVL adult), scale bar $=0.5 \mathrm{~mm}$. ing four adults with sizes above the previously reported size (45.05-51.65 mm LRC). Thus, these two species have indistinguishable fingertips, probably without any ontogenetic changes.

\section{Integumentary sensory receptor: Lateral line}

\section{Neuromasts}

In Pipa, the neuromasts stitches are observable on the body surface as white circles with a diameter below $0.2 \mathrm{~mm}$, and a depression in the middle. These stitches are arranged in lines easily distinguishable in post-metamorphic stages or in individuals with darkly pigmented skin, especially in the dorsum (Fig. 1).

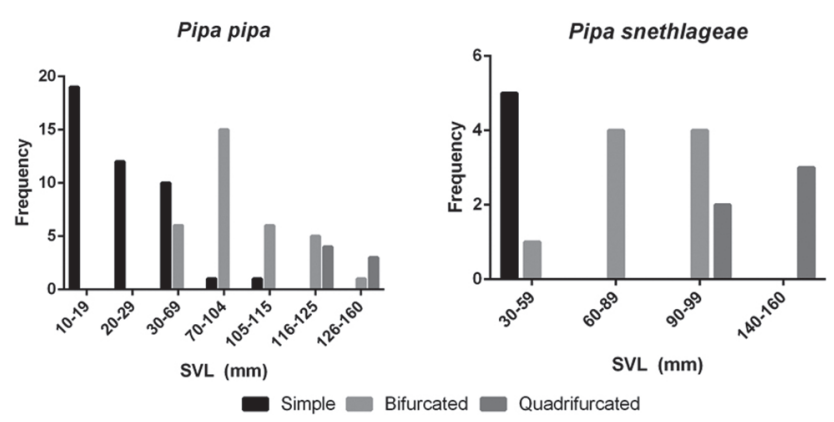

Figure 7. Frequency distribution histograms of fingertip morphology for (A) Pipa pipa and (B) P. snethlageae grouped based on their SVL (mm). Dark grey bars are individuals with simple lobed fingertips, light grey bars are bifurcated, and grey are tetrafurcated. Adult size is reached between 104.7-105.7 mm for P. pipa and $75 \mathrm{~mm}$ for P. snethlageae.

\section{A}
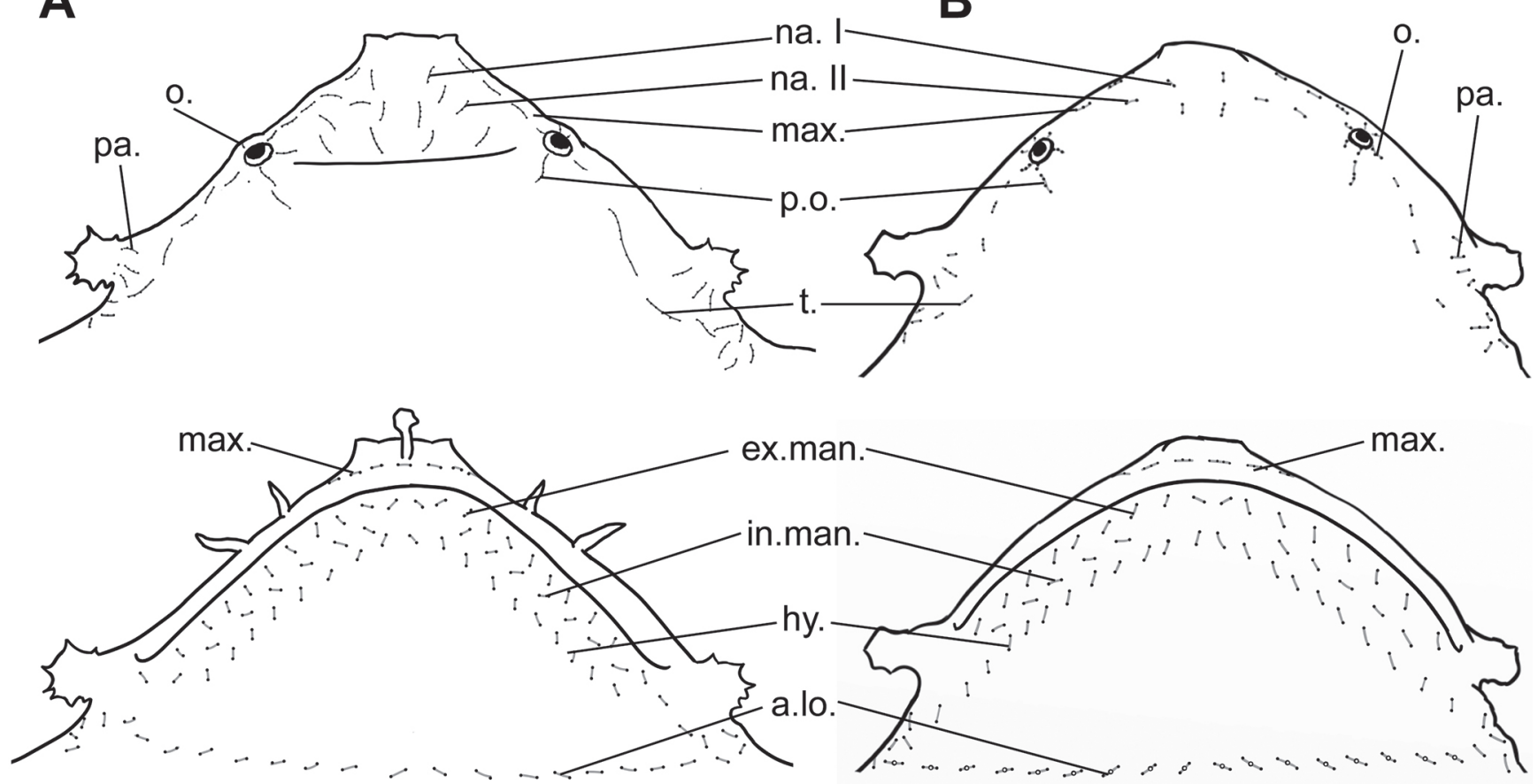

Figure 8. Comparison between the lateral line arrangement both in dorsal and ventral view in the head of (A) P.pipa and (B) P. snethlageae. Nomenclature as follows: a.Io. = anterior lower line; ex.man. = external mandibular; hy. = hyomandibular; in.man. $=$ internal mandibular; $\max .=$ maxillar lines; na. $=$ nasal lines; $0 .=$ orbital lines; p.a. = posterior auditory; p.o. = posterior ocular; $\mathrm{t} .=$ temporal line. Black dots represent neuromasts. 


\section{Lateral line pattern}

Pipa presents neuromasts in four anatomical regions: dorsally, in the cephalic and dorsum regions, and ventral$l y$, in the gular and in the abdominal regions.

The cephalic region of Pipa exhibits a series of organized neuromast lines on the skin surface. Pipa pipa presented more lines in this region than the other species as follows (Fig. 8A): Nasals (I and II), maxillar, orbital, posterior ocular, temporal, and posterior auditory lines. A first group of neuromasts extends medially, in anterior-posterior direction, forming the nasal line I. Transversely to the nasal I, the nasal lines II form towards the upper lip. Over the lip there is another line forming the maxillar line, which can also be seen running under the nostrils in anterior-posterior direction. There are several neuromasts radiating from the eyes called orbitals; two of these extending posteriorly, one towards the medial region forming the posterior ocular line and one that reaches from the forelimb towards the ventral area called the temporal line. There is one last group of short lines associated with the tympanic region in the base of the flaps at the angles of the jaw called the posterior auditory.

Pipa snethlageae included all the lines present in P. pipa with a similar arrangement (Fig. 8B). However, in this species the neuromasts are less abundant in the cephalic region, and the lines have a lower number of stitches, appearing to be more scattered (Fig. 8B).

For both P. myersi and P. parva, the LLS pattern in the cephalic region were the same (Fig. 9). These species present the nasal I and nasal II lines (the latter missing some rows), as well as the maxillar, orbital, posterior ocular and temporal lines. Those lines were shared among all four species, but these two smaller species lack a posterior auditory line (Fig. 9).
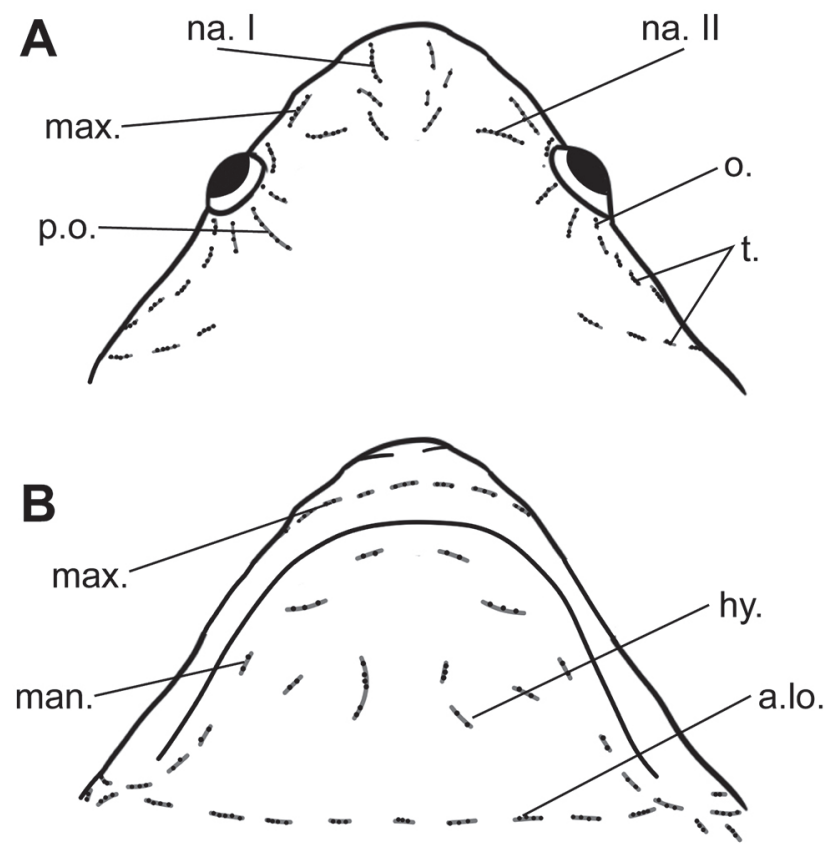

Figure 9. Lateral line arrangement in $(A)$ dorsal and (B) ventral view in the head of $P$. myersi. Nomenclature as in Fig. 5 , man. = mandibular line.

In the dorsal region, the four species present paired occipital, middle, mid-lateral, and lower-lateral lines (Fig. 10). In the anterior-posterior direction, the occipital lines are short and located in the most anterior region of the dorsal surface (Fig. 10). Between the axillary and the groin region, the middle line is located medially in the anterior and middle region of the dorsum. Laterally, mid-lateral and lower-lateral lines start just after the neck and run backwards longitudinally along the body, until they converge medially at the cloaca.

The gular region presents short parallel groups of lines associated with the jaw. In P. pipa y P. snethlageae

A

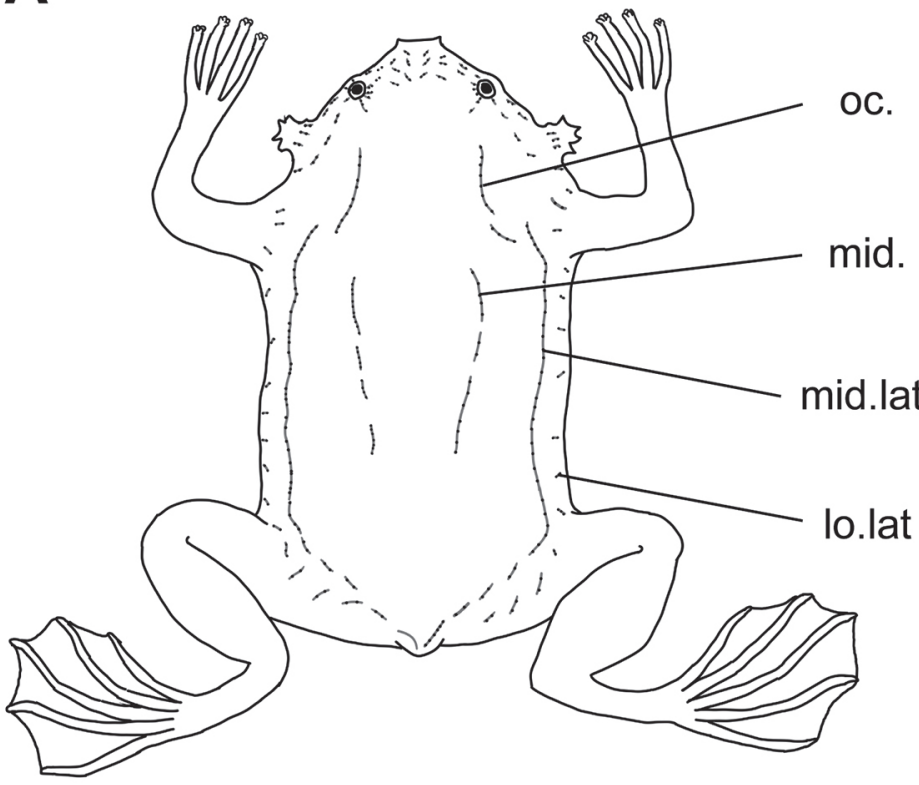

B

Figure 10. Comparison between the dorsal lateral line pattern in the larger and smaller species of the genus (A) P. pipa and (B) P. myersi. Nomenclature as follows: lo.lat. = lower-lateral line; mid. $=$ middle line; mid.lat. $=$ middle lateral line; $0 c .=$ occipital; $p .0 .=$ posterior ocular. Black dots represent neuromasts. 
(Fig. 8), there are three lines: the external mandibular, the inner mandibular, and the third is the hyomandibular line. Posteriorly, they exhibit a necklace-like line called the anterior lower line, which connects with the mandibular lines. This line is also connected to the temporal line in the cephalic region, which runs dorsally and moves downwards behind the flap. There, it forms a shattered group of short lines in the lateral area until it reaches the gular region. For the smaller species of Pipa (Fig. 9), both $P$. myersi and P. parva exhibit a conspicuous external mandibular line and the anterior lower line, but the inner mandibular and hyomandibular ones are shorter and less visible than in other species.

On the abdominal region, all species shared three big groups of shattered neuromasts: a short slightly lateral set of lines which runs sideways across the body, a set of short lines towards the middle line of the animal, and some short lines surrounding the base of the limbs.

\section{Ontogenetic variation}

The difference in P. pipa and $P$. snethlageae when compared between adult and juvenile individuals, was around the middle line. In juveniles, this line was spread to the posterior region on the dorsum, whereas in adults it reached up to the middle of the body.

\section{DISCUSSION}

Variation in the morphology of the tegument can provide useful traits for differentiating species. In this study, several tegument characters and their variation along the ontogeny were considered in four of the seven species of Pipa. Fingertip morphology and the dermal flap have been used for taxonomic accounts in this genus (Trueb \& Cannatella, 1986), but ontogenetic variation has not been considered previously. Although there is still information missing about the anatomy and function of these structures, our results support common traits shared by all four evaluated species. There are also several differences identified along ontogeny and among species.

Interpretation of the occurrence and variation of the dermal flap in species of Pipa has been somewhat controversial (Acosta-Galvis et al., 2016). Our data indicates that this structure is only present in P. pipa and absent in the other species including $P$. snethlageae. Although Trueb \& Cannatella (1986) previously stated this same result, they reported one $P$. snethlageae with a reduced dermal flap in a figure (fig. 16) of their study; as some individuals identified as $P$. snethlageae had a reduced dermal flap, further works have addressed the fact that the dermal flap may not be an autopomorphic characteristic (Lynch \& Vargas-Ramírez, 2000; Acosta-Galvis et al., 2016). In P. pipa, specimens that had a dermal flap shortened or almost absent were observed. This apparently secondary condition could be the result of rapid but violent feeding behavior (Fernandez et al., 2017), or that the structure did not grow in these individuals for some environmental or genetically underlying reason. Thus, the dermal flap is a conspicuous structure for $P$. pipa that sets it apart from other species of Pipa.

Among Pipidae, integumentary structures around the oral region similar to barbels are present in Xenopus larvae. In that genus, the larvae present a pair of tentacle-like structures around the mouth, which have a mechano-receptive function but are later lost after metamorphosis occurs (Cannatella \& Sá, 1993; Fox, 1999). Unfortunately, the internal structure of these short barbels is unknown, but we do not dismiss a similar functionality. Most of the variability found for this structure was around the number of barbels in these two species and, despite the lack of information, we must consider that barbels frequently appear in $P$. pipa and rarely in $P$. snethlageae. Further works should address the anatomy and ecological significance of barbels.

Within the integument, the LLS is spread across the body in Pipa with a cephalic, dorsal and ventral pattern. The four species analyzed shared the dorsal pattern but differed in the cephalic and gular area. In comparison with the other species of Pipa, P. carvalhoi also presents three lines in the dorsum (Trueb \& Cannatella, 1986); the general pattern resembling the one found in $P$. myersi and $P$. parva. In contrast, the lateral line pattern of $P$. arrabali and $P$. aspera are poorly understood. A review of this arrangement in the remaining species of Pipa is needed to confirm our assumption that the distribution of the dorsal neuromasts is a common trait among the genus that sets them apart from the arrangement of their phylogenetic African relatives (Shelton, 1970).

Pipa parva and P. myersi were highly similar in all LSS pattern but divergent from $P$. pipa and $P$. snethlageae, which presented a greater number of lines on the cephalic and gular area. The cephalic pattern also differed between the latter two species, since $P$. pipa exhibited more lines than $P$. snethlageae. There is no information for the other species, but this result regarding our focal species indicates that the lateral line is a powerful characteristic with taxonomic utility for the genus Pipa.

The lack of differences in the lateral line pattern along ontogeny in Pipa is possibly related to the aquatic habitat use, direct development, and similar strategies for foraging in juveniles and in adults (Rabb \& Snedigar, 1960). Changes in the lateral line pattern are only seen in pipid species with larval stage; for instance, in tadpoles of $X$. laevis the pattern changes during metamorphosis, in which adults develop more neuromasts along the snout (Shelton, 1970). The increasing amount of lateral line elements along the head responds to the need of perceiving water currents to avoid predation and detect possible preys (Shelton, 1970; Winklbauer, 1989). This highlights the functional value of the arrangement of lines in the cephalic and oral region, which could be related to different ecological conditions for these species (Elepfandt \& Wiedemer, 1987; Janssen, 1997). Further studies are necessary to understand its functional role and detection capabilities, and as P. carvalhoi, P. myersi and P. parva bear a larval stage (Trueb \& Cannatella, 1986), morphological changes may occur in relation to their ecology. 
Regarding the smaller species, $P$. myersi shared the same LLS pattern on the body, tubercles, and fingertip morphology with its sister species $P$. parva; both presenting two distal and two more lateral and proximal lobes. The original descriptions of these species were based on the few specimens available at the time (Ruthven \& Gaige, 1923; Trueb, 1984), and neither species had major differences in external morphology with the description besides this last character (Trueb \& Cannatella, 1986; this study). We had access to larger individuals than previous reports on $P$. myersi (37-51 mm SVL, Table 1). In fact, the sizes overlapped with $P$. parva ranging from 29.93-49.67 mm SVL (Trueb, 1984; Trueb \& Cannatella, 1986). Our larger sample provides a more robust point of comparison for external morphological traits, especially the fingertips.

As both species showed the same fingertip morphology across all the ontogenetic stages reviewed, there is a difference from the trifurcated fingertips found in the original description of this species (Trueb, 1984). This disparity may be due to poor fixation or preservation of specimens, which were frequent in some old material in biological collections. Another possible explanation for this discordance may be that fingers may have suffered a teratogenic process that leads them to form a trifurcated fingertip. A similar observation could be made in relation to two $P$. pipa specimens with globular fingertips (pers. obs.). Therefore, the absence of differences in $P$. parva and $P$. myersi regarding fingertip morphology indicates that this diagnostic feature is not useful for separating these species.

Pipa parva and $P$. myersi specimens had either mostly spiny tubercles or smooth plates in the dorsum. This provides evidence that tubercles appear as a sexually dimorphic character (Kretschmer \& Greven, 2009) in these smaller species, although we could not directly confirm the sex of the specimens. Studies on osteological features support the status of these species, especially the cranium morphology. However, previous work of Trueb \& Cannatella (1986) compared specimens that were not of the same size, thus probably influencing their results. The disjoint geographic distribution of $P$. parva and $P$. myersi and the external morphology are evidence that a review of these osteological and other diagnostic characteristics is necessary considering that these species are also highly similar in the body, head and snout form (pers. obs.). Hence, the inclusion of molecular approaches could further resolve the taxonomic identity and evolutionary history of these species.

In general, the lobes on the fingertips showed interesting arrangements on each species, especially for both $P$. pipa and $P$. snethlageae which presented the same series of divisions on fingertips but different arrangement of them. The ontogenetic influence is the key factor explaining the changes in the number of observed lobes. Previous work by Filek (1967) and Ehrl et al. (1987) brought to attention that not all specimens of $P$. pipa have four bifurcated lobes. However, these observations were made with few specimens. Our series of $P$. pipa of different sizes show how, from four simple lobes in post-meta- morphic specimens and most juveniles, the lobes further bifurcate according to the growth of the frog (Fig. 7). This development of the fingertips does not fit the traditional understanding of the structure thus showing how some characters may vary even among grown up adult specimens, a fact which is not usually included in species descriptions. Although Pipa seems to be a special case, a fairly complete consideration of a series of stages of a species provides a lot more information about the morphology of the species and establishes better supported characteristics for taxonomic purposes than a traditional approach.

Since the number of lobes on each fingertip are no longer useful for distinguishing between $P$. pipa and $P$. snethlageae, we want to address some other useful diagnostic features of these species. Although for both species the head is flattened in lateral view, for $P$. pipa the head is more acuminated in dorsal view and the snout is pointy and more truncated than for $P$. snethlageae (Trueb \& Cannatella, 1986; Fig. 8). Pipa snethlageae has a more obtuse head in dorsal view than P. pipa (pers. obs) and the snout is rounded (Müller, 1914; Trueb \& Cannatella, 1986; Fig. 8). Besides the relative position of the lobes of the fingertips, the greater number of neuromast stitches in P. pipa contrast with the lower amount in P. snethlageae in cephalic region. Additionally, diagnostic traits for $P$. pipa are the dermal flap and the usual presence of barbels which, are absent in the smaller species.

\section{CONCLUSION}

The tegument of new-world pipids showed variability in the intra and interspecific context in which some traits may change along ontogeny. All four species shared a lateral line pattern along the dorsum of the body which we propose may be a common trait of the genus. Our results support that the fingertip morphology, frequently used for taxonomic purposes, can be misleading as previously understood. We observed a divergent condition from the original descriptions in P. myersi with four lobes instead of three. Similarly, differences in the number of lobes for $P$. pipa and $P$. snethlageae across sizes showed that, in these species, the lobes continuously grow along the ontogeny of the frog. In turn, P. myersi and P. parva are highly similar in their LLS pattern, fingertips, tubercles, and the lack of oral appendages. On the other hand, P. pipa and P. snethlageae are similar in the arrangement of the lobes but different in the amount of neuromast in the snout, which is higher for P. pipa. Additionally, P. pipa was the only species in which the dermal flap was present and usually (>80\%) showed barbels, rare to find in $P$. snethlageae. In this study, we reviewed and clarified some taxonomic discrepancies among Colombian Pipa but also highlighted how dynamic and variable anuran tegument can be, even in adult stages. Finally, these tegument structures require further studies, regarding histology and a functional role related to ecological conditions of these peculiar frogs. 
AUTHORS' CONTRIBUTIONS: SEP-R: Methodology, Data curation, Project administration, Visualization; AJ: Supervision; SEP-R, AJ: Conceptualization, Investigation, Resources, Validation, Writing - original draft, Writing review \& editing. All authors actively participated in the discussion of the results, they reviewed and approved the final version of the paper.

CONFLICTS OF INTEREST: Authors declare there are no conflicts of interest.

FUNDING INFORMATION: This project did not use any external financial support.

ACKNOWLEDGMENTS: We want to dedicate this work to María Cristina Ardila-Robayo for all her guidance and work as a professor and investigator for many Colombian researchers. She personally helped us to start this project, and although she unfortunately could not see the results of it, we want to thank her. We thank the curators and collections that allowed us to visit and collect our data for this study, John D. Lynch (Colección de Anfibios, Instituto de Ciencias Naturales), Julio Mario-Hoyos (Universidad Javeriana), Pablo Palacios (Universidad de los Andes), Andrés Acosta-Galvis (Instituto de Investigación de Recursos Biológicos Alexander von Humboldt), Mariela Osorno Muñoz (SINCHI) and María Fernanda Lozano Bernal and Fernando Sarmiento (Universidad de la Salle). Also, to the Laboratorio de Anfibios where most of the work was done and the Laboratorio de Equipos Ópticos Compartidos of the Departamento de Biología (Universidad Nacional de Colombia, Sede Bogotá). Thanks to Alina Machnicki and Stephane Bryant for editing the English and thanks to Gabriela Perez, Valentina Martinez Salazar, Juliana Rodríguez, Martha L. CalderónEspinoza and all the colleagues that helped us with the final version of the manuscript.

\section{REFERENCES}

Acosta-Galvis, A.R.; Lasso, C.A. \& Morales-Betancourt, M.A. 2016. Ranas del género Pipa (Anura: Pipidae) de la Orinoquia colombiana: nuevos registros y comentarios sobre su taxonomía, distribución e historia natural. Biota Colombiana, 17(2): 105-116. https://doi.org/10.21068/ c2016.v17n02a08.

Alves-Pinto, H.N.; Verdade, V.K. \& Rodrigues, M.T. 2014. Morphometric variation of Pipa pipa (Linnaeus, 1758) (Anura: Pipidae) with notes on diet and gonad development. Herpetology Notes, 7: 347-353. https:// bdpi.usp.br/item/002482601.

Bewick, A.J.; Chain, F.J.J.; Heled, J. \& Evans, B.J. 2012. The Pipid Root. Systematic Biology, 61(6): 913-926. https://academic.oup.com/sysbio/ article/61/6/913/1663746.

Cannatella, D.C. \& de Sá, R.0. 1993. Xenopus laevis as a model organism. Systematic Biology, 42(4): 476-507. https://doi.org/10.1093/ sysbio/42.4.476.

Cannatella, D.C. \& Trueb, L. 1988. Evolution of pipoid frogs: Intergeneric relationships of the aquatic frog family Pipidae (Anura). Zoological Journal of the Linnean Society, 94(1): 1-38. https://doi. org/10.1111/j.1096-3642.1988.tb00880.x.
Carvalho, I. de S.; Agnolin, F.; Aranciaga Rolando, M.A.; Novas, F.E.; XavierNeto, J.; Freitas, F.I. \& Andrade, J.A.F.G. 2019. A new genus of pipimorph frog (Anura) from the Early Cretaceous Crato Formation (Aptian) and the evolution of South American tongueless frogs. Journal of South American Earth Sciences, 92: 222-233. https://doi.org/10.1016/j. jsames.2019.03.005.

Cochran, D.M. \& Goin, C.J. 1970. Frogs of Colombia. Washington, D.C., Smithsonian Inst. Press. https://repository.si.edu/handle/10088/10050.

Conlon, J.M. \& Mechkarska, M. 2014. Host-defense peptides with therapeutic potential from skin secretions of frogs from the family Pipidae. Pharmaceuticals, 7(1): 58-77. https://doi.org/10.3390/ph7010058.

Duellman, W.E. \& Trueb, L. 1994. Biology of Amphibians. Baltimore, The Johns Hopkins University Press.

Dunn, E.R. 1948. American frogs of the family Pipidae. American Museum Novitates, 1384: 1-13.

Ehrl, A.; Schutte, F. \& Herbig, A. 1986. Scanning electron micrography of the digital tip of Pipa pipa (Anura: Pipidae). In: Rocek, Z. (Ed.). Proceedings of the European Herpetological Meeting (3rd Ordinary General Meeting of the Societas Europaea Herpetologica). Charles University. p. 259-262.

Ehrl, A.; Schütte, F. \& Herbig, A. 1987. Morphology and development of fingertips in frogs of the genus Pipa (Anura: Pipidae). In: van Gelder, J.J.; Strijbosch, H. \& Bergers, P.J.M. (Eds.). Proceedings of the 4th Ordinary General Meeting of the Societas Europaea Herpetologica. Nijmegen. p. 123-126.

Elepfandt, A. \& Wiedemer, L. 1987. Lateral-line responses to water surface waves in the clawed frog, Xenopus laevis. Journal of Comparative Physiology, 160(5): 667-682. https://doi.org/10.1007/BF00611939.

Fernandez, E.; Irish, F. \& Cundall, D. 2017. How a Frog, Pipa pipa, succeeds or fails in catching fish. Copeia, 105(1): 108-119. https://doi.org/10.1643/ CH-16-510.

Filek, W. von. 1967. Frösche im Aquarium. Franckh'sche Verlagshandlung.

Fox, H. 1999. Barbels and barbel-like tentacular structures in sub-mammalian vertebrates: A review. Hydrobiologia, 403: 153-193. https://doi. org/10.1023/A:1003778125517.

Frost, D.R. 2020. Amphibian Species of the World: an online reference. Available: https://amphibiansoftheworld.amnh.org/index.php. Access: 19/05/2019.

Greven, H. \& Richter, S. 2009. Morphology of skin incubation in Pipa carvalhoi (Anura: Pipidae). Journal of Morphology, 270(11): 1311-1319. https:// doi.org/10.1002/jmor.10759.

Janssen, J. 1997. Comparison of response distance to prey via the lateral line in the ruffe and yellow perch. Journal of Fish Biology, 51(5): 921-930. https://doi.org/10.1111/j.1095-8649.1997.tb01531.x.

Kretschmer, S. \& Greven, H. 2009. Sexual dimorphism of the skin surface in Pipa parva (Anura: Pipidae). Salamandra, 45(4): 251-253. http://www.salamandra-journal.com/index.php/home/ contents/2009-vol-45/20-kretschmer-s-h-greven/file.

Lynch, J.D. \& Vargas Ramírez, M.A. 2000. Lista preliminar de especies de anuros del departamento del Guainía, Colombia. Revista de la Academia Colombiana de Ciencias Exactas, Físicas y Naturales, 24(93): 579-589.

Mariano, D.O.C.; Yamaguchi, L.F.; Jared, C.; Antoniazzi, M.M.; Sciani, J.M.; Kato, M.J. \& Pimenta, D.C. 2015. Pipa carvalhoi skin secretion profiling: Absence of peptides and identification of kynurenic acid as the major constitutive component. Comparative Biochemistry and Physiology Part C: Toxicology \& Pharmacology, 167: 1-6. https://doi.org/10.1016/j. cbpc.2014.08.001.

Müller, L. 1914. On a new species of the genus Pipa from northern Brazil. Annals and Magazine of Natural History, Series 8(14): 102.

Quinzio, S. \& Fabrezi, M. 2014. The lateral line system in anuran Tadpoles: neuromast morphology, arrangement, and innervation: the lateral line 
system in anuran Tadpoles. The Anatomical Record, 297(8): 1508-1522. https://doi.org/10.1002/ar.22952.

Rabb, G.B. \& Rabb, M.S. 1960. On the mating and egg-laying behavior of the Surinam Toad, Pipa pipa. Copeia, 1960(4): 271. https://doi. org/10.2307/1439751.

Rabb, G.B. \& Snedigar, R. 1960. Observations on breeding and development of the Surinam Toad, Pipa pipa. Copeia, 1960(1): 40. https://doi. org/10.2307/1439843.

Ruthven, A.G. \& Gaige, H.T. 1923. Description of a new species of Pipa from Venezuela. Occasional Papers of the Museum of Zoology, University of Michigan, 136: 1-2.

Schütte, F. \& Ehrl, A. 1987. Zur Haltung und Zucht der großen südamerikanischen Wabenkröte Pipa pipa (Linnaeus, 1758) (Anura: Pipidae). Salamandra (Frankfurt am Main), 23(4): 256-268.

Shelton, P.M.J. 1970. The lateral line system at metamorphosis in Xenopus laevis (Daudin). Journal of Embryology and Experimental Morphology, 24(3): 511-524.
Trueb, L. 1984. Description of a new species of Pipa (Anura: Pipidae) from Panama. Herpetologica, 40(3): 225-234.

Trueb, L. \& Cannatella, D.C. 1986. Systematics, morphology, and phylogeny of genus Pipa (Anura: Pipidae). Herpetologica, 42(4): 412-449.

Trueb, L.; Púgener, L.A. \& Maglia, A.M. 2000. Ontogeny of the bizarre: An osteological description of Pipa pipa (Anura: Pipidae), with an account of skeletal development in the species. Journal of Morphology, 243(1): 75-104. https://doi.org/10.1002/ (SICI)1097-4687(200001)243:1<75::AID-JMOR4>3.0.C0;2-L.

Vitt, L.J. \& Caldwell, J.P. 2014. Herpetology an introductory biology of amphibians and reptiles. 4.ed. Amsterdam, Academic Press.

Winklbauer, R. 1989. Development of the lateral line system in Xenopus. Progress in Neurobiology, 32(3): 181-206. https://doi. org/10.1016/0301-0082(89)90016-6.

Zippel, K.C. 2006. Further Observations of Oviposition in the Surinam Toad (Pipa pipa), with Comments on Biology, Misconceptions, and Husbandry. Herpetological Review, 37(1): 60-68. 


\section{APPENDIX 1}

\section{Specimens examined in this study (number of specimens in parentheses).} Abbreviations for collections as in Materials and Methods.

Pipa pipa ( $\mathrm{n}=83$ ): COLOMBIA: Amazonas: ICN 46654, ICN 46668, ICN 51556-61, ICN 51564, ICN 51567-69; Leticia: MLS 809, MLS 810; Arca de Leticia, ICN 218; PNN Amaca-Yacu: ICN 13956; km 11 vía Leticia-Tarapacá, ICN 46862, ICN 51555, ICN 51562; Carretera Leticia-Tarapacá, Tanimboca, Andes-A 751; km 9-10 carretera, Andes-A 926; Río Takana, km 9 carretera, Andes-A 1713; Cantadero cerca de Monilla Asena, ICN 51563, ICN 51565-66; Reserva Natural Park, Andes-A 2154; Puerto Nariño: Sector de lagos de Tarapoto, IAvH-Am 10574; Puerto Zancudo: MLS 647; Arauca: Arauca: IAvH-Am 6289; Caquetá: Valparaiso: Curbinata, SINCHI 151; Solita: La Recreo, SINCHI 256; San Vicente del Caguán: SINCHI 4688 Guainía: Inírida: SINCHI 1707, SINCHI 1709, SINCHI 2057, SINCHI 2129, SINCHI 2130; Guaviare: Miraflores: SINCHI 5595-96, SINCHI 5624; San José del Guaviare: Playa Güio, ICN 56711-12; Meta: Puerto López: ICN 13959-13966; km 5 vía Puerto López-Alto Menegua, IAvH-Am 4104-4105; La Macarena: IAvH-Am 1888; Vichada: Caño Muñeco, IAvH-Am 14738; Cumaribo: SINCHI 5093, SINCHI 5234, SINCHI 5249, SINCHI 5250; Puerto Carreño: Vereda La Libertad, IAvH-Am 11848; Reserva natural protectora Bojonawi, IAvH-Am 11936-11939, IAvH-Am 11982; Vereda El Tomo: IAvH-Am 14711, IAvH-Am 14726; Vaupés: Comunidad de Buenos Aires, SINCHI 5330-31; Comunidad Puerto Vaupés, ANDES-A 2156; Taraira: Comunidad Jotabeyá, ICN 56996; Imprecise data: Colombia: Llanos orientales Andes-A 231; Unknown locality: Colombia: MUJ 786-799, ACG 78 (in Andes-A).

Pipa snethlageae $(n=19)$ : BRASIL: Río Yavarí, frontera Brasil-Perú frente a Leticia, IAvH-Am 666; COLOMBIA: Amazonas: ICN 46653; Puerto Nariño: río Tarapota, IAvH-Am 2814; PNN Amacayacú, IAvH-Am 6748; Caquetá: Solano: PNN Chibiriquete río cuñare AMU, IAvH-Am 6780; Guainía: Comunidad Berrocal, río Guainía, Andes-A 2151; Laguna Pavon, caño Naquen, Andes-A 2152; Comunidad San Jose, río Guainía, Andes-A 2153; Inírida: Caño Caimán, ICN 39026; Inirida: Caño Agujón ICN 41167; Inírida: IAvH-Am 474 SINCHI 1708 SINCHI 1710; Vichada, Cumaribo: Sector matavén Fruta Sejal, SINCHI 5092, Puerto Carreño, vereda Caño Negro, La Pedregoza, ICN 57340; Puerto Carreño, Reserva Natural Privada Bojonawi, IAvH-Am 11982, IAvH-Am 14243, Río Orinoco: IAvH-Am 7582; Imprecise data: COLOMBIA: Llanos orientales Andes-A 232.

Pipa myersi $(n=15)$ : COLOMBIA: Antioquia: Bananera Santa Elena, 0.5 km N de Carepa, ICN 57410; Turbo: Corregimiento Lomas Aisladas, IAvH-Am 10309-10319; Chocó: Acandí: Corregimiento de Gilgal, ICN 2399, ICN 47395-96.

Pipa parva ( $\mathrm{n}=13)$ : COLOMBIA: Norte de Santander: Inspección de policía Tibú, ICN 13955; Cúcuta: alrededores de Cúcuta, ICN 10847; Quebrada Patillales, IAvH-Am 14560-61; Chinácota: ICN 33535-39; El Zulia:Vereda Pedregales, km 21 carretera El Zulia-Sardinata, ICN 33602; Hacienda Astillero, río Zulia, MLS 270, MLS 805-807.

\section{APPENDIX 2}

Additional dermal flap morphologies found in adult specimens of Pipa pipa. Dermal flap (A) distally flattened and lobed, (B) flattened with tubercles, (C) cylindrical, and (D) lobed.
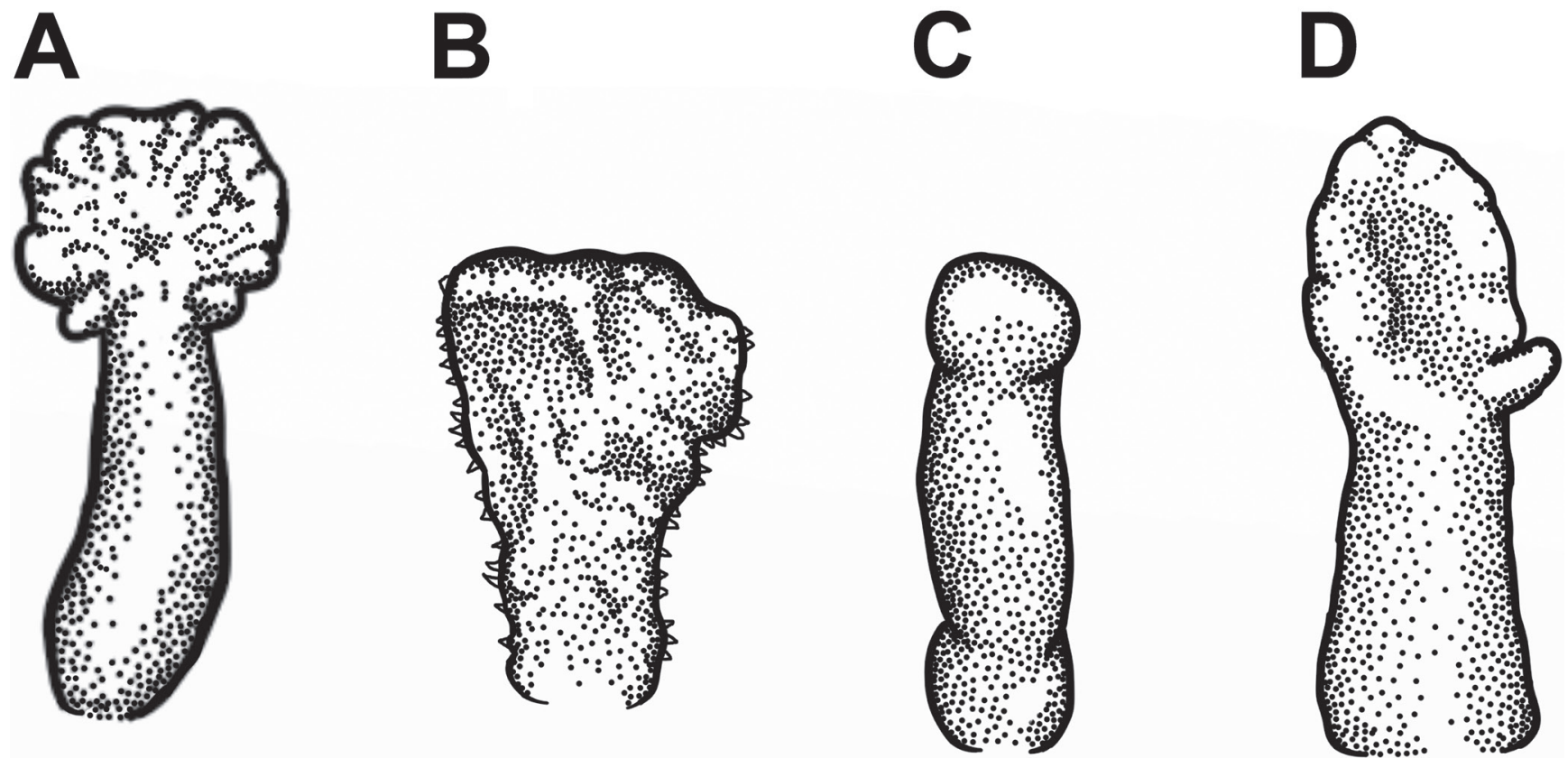